\title{
A fuzzy-based evaluation of financial risks in build-own-operate-transfer water supply projects
}

\author{
Ameyaw E. Effah, $\mathrm{PhD}^{1}$; Albert Chan, $\mathrm{PhD}^{2}$; De-Graft Owusu-Manu, $\mathrm{PhD}^{3}$; David J. Edwards ${ }^{4}$; \\ Frederick Dartey ${ }^{5}$
}

\section{Abstract}

The Build-own-operate-transfer (BOOT) scheme is widely used for the provision of new bulk water supply. However, this scheme is complex and carries significant financial risks, due to the characteristics of the water sector and the involvement of public-private stakeholders with new and extended responsibilities, large private capital, and long contract duration. Drawing on the Nungua Seawater Desalination Plant (NSDP) in Ghana, this research seeks to identify and assess the critical financial risks associated with BOOT water supply projects and evaluate the financial risk level of the NSDP project. The risks and their relative criticality on the NSDP project are investigated by using a questionnaire survey method. The questionnaire was formulated with a set of 18 risks derived from extant literature and project documentation. Perceived critical financial risks affecting the NSDP project were assessed by a team of experts who had direct involvement in the project. A fuzzy synthetic evaluation suggests that the case project is financially risky and that all the risks are critical to the project. Bankruptcy of consortium members, unfavourable economy of the host country, uncertainty in the tariff adjustment of water products, rate of return (profitability) restrictions, and availability problem of private capital are the five most highly-ranked risks. The fuzzy technique is used to represent and model the experiential knowledge of survey participants and to address the fuzziness of their expert judgments. The study's results facilitate prioritization of risks and a comprehensive risk management program during the lifecycle of the case project and future projects. The fuzzy technique is suitable for early phases of BOOT projects to prioritize the risks that require a detailed analysis and to predict the risk level of a project.

Keywords: Build-own-operate-transfer (BOOT), fuzzy synthetic evaluation, water supply, financial risk.

\section{Introduction and research background}

Build-own-operate-transfer (BOOT) arrangements have been used internationally as a means to develop new infrastructure assets. The BOOT scheme is particularly suitable for the delivery of bulk water supply (Lianyu and Tiong, 2005). From 1990 to 2011, 58\% (439 projects) of

\footnotetext{
${ }^{1}$ Department of Building and Real Estate, The Hong Kong Polytechnic University, Hong Kong (corresponding author). Email: myernest2010@yahoo.com

${ }^{2}$ Department of Building and Real Estate, The Hong Kong Polytechnic University, Hong Kong

${ }^{3}$ Department of Building Technology, Kwame Nkrumah University of Science and Technology.

${ }^{4}$ Faculty of Technology Environment and Engineering, Birmingham City University, United Kingdom

${ }^{5}$ PPP Advisory Unit, Ministry of Finance, Ghana.
} 
private activities in developing countries involved water and wastewater treatment. Among which, $31 \%$ (136 projects) were drinking water supply (World Bank, 2012). The BOOT model has the advantages of assigning the risk of delivering a new bulk water supply on budget and on time to the private sector, improving the efficiency of project delivery, and mobilizing new sources of funding for fast project development (World Bank, 2014). The model has become an increasingly important route for bulk water supplies because such arrangement increases the capacity of water systems to provide potable water to a growing number of customers.

Under the BOOT scheme ${ }^{1}$, the private developer performs new and extended responsibilities, such as raising project funds, designing and constructing facilities required to deliver the bulk water supply, and operating and maintaining these facilities, with a return on capital secured through a long-term off-take agreement (Wall, 2013; Lianyu and Tiong, 2005; Donaghue, 2002). Ownership and operating rights belong to the private entity until the expiration of the concession period, after which these rights are transferred to the public party. In this research, BOOT includes all concession-type contracts in which finance is provided primarily by the private sector to develop infrastructure assets. Variations generally adopt the primary functions of the BOOT model and include build-operate-transfer (BOT), design-build-operate-transfer, finance-build-own-operate-transfer, build-transfer-operate, build-lease-transfer, and design-build-operate. Utility concessions are excluded from consideration in this paper ${ }^{2}$. However, where necessary, 'public-private partnership (PPP)' is also used to denote general forms of private sector participation, including BOOT/its variants and utility concessions/PPPs.

BOOT projects entail large private capital, a long concession period and multiple stakeholders which in turn, result in an array of major risks, including political and legal risks $(\mathrm{Ng}$ and Loosemore, 2007; Merna and Smith, 1996), social risks (Wibowo and Mohamed, 2010; Rebeiz, 2012), technical risks (Özdogan and Birgönül, 2000; Zeng et al., 2007), and financial risks (Xenidis and Angelides, 2005; Lam and Chow, 1999). In this study, financial risks in BOOT for water supply are identified and analyzed. Financial risks occur frequently and affect water infrastructure projects significantly (Ameyaw and Chan, 2015a), given the difficulty in obtaining long-term financing in local currency for water projects (Matsukawa et al., 2003). This creates a mismatch between currencies of financing and revenues. The mismatch, coupled with depreciations of the local currency, has a damaging effect on the sustainability and profitability of BOOT water supply projects (Vives et al., 2006; Lianyu and Tiong, 2005). Tackling problem via pass-through provisions in the contracts has been ineffective because 
the population is often unable to pay for the associated rate hikes. Financial risks are also associated with higher inflation rates, higher capital costs and lower operating margins or forecasted revenues, and therefore are widely linked to rising project failures (Lee and Schaufelberger, 2014; Vives et al., 2006).

Although there is a a myriad of literature on the general risks in BOOT projects across infrastructure sectors (e.g., Ameyaw and Chan, 2015a; Lee and Schaufelberger, 2014; Rebeiz, 2012; Wibowo and Mohamed, 2010; Ng and Loosemore, 2007; Zeng et al., 2007), there are limited studies on, and hence a less understanding of, financial risks affecting water projects especially in developing countries (Organisation for Economic Co-operation and Development, OECD, 2009). Developing countries are associated with higher risks resulting from unfavorable local conditions, such as macroeconomic factors, tariff sustainability, user willingness to pay, legal frameworks, political factors, institutional capacity and fiscal space (Vives et al., 2006; Matsukawa et al., 2003). These issues influence conditions of investment and private sector's investment decision-making. A review of literature revealed three prominent studies focused upon financial risks in BOOT projects (Xenidis and Angelides, 2005; Wang et al., 2000; Lam and Chow, 1999) but these did not consider financial risks in water BOOTs. This explains a paucity of understanding regards the risks affecting water projects (OECD, 2009) and also sheds some light on why project structures often fail to match prevailing risks (Vives et al., 2006). Moreover, Cheung and Chan (2011) showed that important risks faced by privatised water projects differ from those encountered in transportation and power projects. This suggests a need for a water sector-specific investigation of risks.

\section{[Insert Table 1]}

BOOT water supply projects partly face financial risks to design and construct due to the sector's challenging characteristics which differentiate it from other infrastructure sectors. , These characteristics result from the following (Ameyaw and Chan, 2015; see Ameyaw and Chan (2013) for discussion):

- Water infrastructure projects are associated with huge initial capital, lengthy payback periods and lower rates of return;

- Water assets are highly specific and immobile (with approximately $80 \%$ fixed underground);

- Critical political and social implications of water services include underpricing and public resistance to private participation; and 
- Water utilities tend to be natural monopolies with a limited possibility for competition.

These attributes could explain the difficulties encountered Failure to carefully identify, prioritize, and mitigate them often result in problems in project development and operation/maintenance (Cuttaree, 2008; Vinning et al., 2005). Several cases of distressed/disputed, terminated, or initially unsuccessful BOOT water supply projects have been reported, including the Beijing No. 10 Water Scheme, the Chengdu No. 6 Water Plant B, and the 9th Shen Yang Water Plant in China; the Thu Duc Water Plant in Vietnam; the Bogota Treatment Plant in Columbia; the Tampa Bay Desalination Plant in Florida, USA; and the Sonia Vihar Water Plant in India (Zhang and Biswas, 2013; Barnett, 2007; Hall and Lobina, 2006; Vinning et al., 2005). The lack of understanding and adequate assessment and management of inherent risks are notable root causes of failure on BOOT projects (Lee and Schaufelberger, 2014; Li and Zou, 2011; Cuttaree, 2008). For example, Aguas del Tunari withdrew from the US\$2.5 billion, 40-year water utility concession in Cochabamba, Bolivia following violent protests partly brought about by failure to assess the public's willingness to pay higher tariffs (Cuttaree, 2008) $)^{3}$.

In order to investigate the important financial risks associated with BOOT water projects, a questionnaire survey was conducted on the Nungua Seawater Desalination Plant (NSDP) project, Ghana. The objectives were to:

1. Identify and assess critical financial risks associated with BOOT water supply projects. Perceptual rankings are gathered from a targeted team of expert participants working on the NSDP project.

2. Conduct an evaluation of the financial risk level of the NSDP project. By using the fuzzy synthetic evaluation (FSE) method, an aggregated index (score) is generated representing the perceived financial risk level of the BOOT project.

Perceptual data were collected about the NSDP project through a questionnaire survey. The FSE method was used to represent and model the experiential knowledge of key project participants and address the fuzziness of their expert judgments. The project's description and the FSE were introduced in the research methods section. Awareness and understanding of the critical financial risks on the NSDP would enable management to take appropriate risk mitigation strategies to reduce project risk level and ensure a successful project delivery.

\section{Financial risk}


137 The term 'financial risk' has variations, as different authors include various factors in their risk

138 lists. Lam and Chow (1999) included counter party, defective products, force majeure, slow

139 progress of works and sovereign risks, while Xenidis and Angelides (2005) included risks such

140 as bankruptcy, prolonged negotiation, lack of guarantees, and rate of return restriction. For this

141 research, the definition of financial risk in BOOT projects proposed by Xenidis and Angelides's

142 (2005) was adopted, namely events that "negatively impact on the cash flows of the financial

143 plan in a way that endangers [a] project's viability or limits its profitability" (p. 433). This

144 research considers only risks of an economic nature.

145

146 Research methods

147 To achieve the research objectives, four iterative stages were undertaken: (1) a background

148 review of the FSE tool for analysis; (2) a review of literature and project documentation to

149 identify the relevant financial risks associated with BOOT water supply projects; (3) a

150 questionnaire survey with a team of participants to assess the risks shortlisted in step two. The

151 participants included developers/promoters, consultants and government representatives; and

152 (4) an analysis of survey data using the FSE technique, which generated a numerical aggregated

153 score to represent the perceived risk level of NSDP.

154

155

Mathematical tool for analysis: Fuzzy set, and FSE

156

Selecting a mathematical tool for assessing risks is influenced by the nature of the problem and the purpose of analysis. During the early stages of BOOT projects, risks should be identified to aid risk planning and management (Boussabaine, 2014). However, given limited project data and information during this stage, the risk identification process draws upon qualitative risk analysis which involves prioritizing risks for further analysis or action by assessing their potential impact on the project (Project Management Body of Knowledge $\AA$, 2008). This condition is considered a qualitative multicriteria analysis problem.

Fuzzy set theory is suitable for qualitative multicriteria analysis because of its capability to resolve or analyze inaccurate and complex decision problems that result from partial and imprecise information that characterize real projects (Boussabaine, 2014; Li and Zou, 2011; Tah and Carr, 2000; Boussabaine and Elhag, 1999). The fuzzy set approach has a rigorous quantitative mathematical theory (Chen and Hang, 1992) that enables systematic processing of qualitative and imprecise information (Khatri et al., 2011). A risk in a fuzzy environment has sets of values that are described by linguistic terms. These qualitative linguistic terms can be 
171 expressed numerically by fuzzy sets. Each set is characterized by a membership function

172 ranging between $[0,1]$, where 0 represents a non-member- and 1 denotes a full member. FSE

173 is one application of the fuzzy multicriteria decision-making techniques considered suitable for 174 this research (Hsiao, 1998).

175

176 A major advantage of FSE is that the analysis does not require a statistically significant sample

177 size (Li et al., 2000; Ameyaw and Chan, 2015b). The input data in FSE analysis are based on

178 experts' perceived value judgements. FSE synthesizes various individual elements of an

179 evaluation into an aggregated index (Khatri et al., 2011). The simplicity of the FSE is that

180 experts' judgements are required for only the sub-criteria (lower-level attributes), whose

181 membership functions are used to derive the membership functions of the upper-criteria (higher-level attributes). This alleviates the need for a complicated questionnaire design.

184 Further, given its theoretical basis in fuzzy set theory (Zadeh, 1965), the FSE approach to risk assessment extends to subjective and uncertain phenomena (Boussabaine and Elhag, 1999); Fuzzy set theory was originally developed to handle these concepts with ease (Jato-Espino et al., 2014). Subjectivity stems from unavailable and incomplete information surrounding risks and the project itself, and the partial ignorance of decision makers (Sadiq and Rodriquez, 2004). The decision maker is unable to provide a precise numerical definition regards the degree of exposure of the project to risks. Hence, the individual and collective impact levels of evaluated risks on the project remain uncertain. The extent of subjectivity and uncertainty in risk criticality assessment are modeled by linguistic values of a fuzzy nature, such as not critical, very low criticality, moderate criticality, and high criticality (see Table 5). Linguistic values provide a means to model "human intolerance for imprecision by encoding decision-relevant information into labels of fuzzy set" (Boussabaine and Elhag, 1999). The estimate of these linguistic values is frequently based on the experience and know-how of the decision maker from similar past projects and his/her knowledge on the present project. These linguistic values are defined to suit the project context. In this study, a common language to describe risk criticality is proposed (Table 5) to ensure consistent evaluation and quantification of the risk index (Tah and Carr, 2000). The linguistic values are defined in a manner that enables an aggregation of all risk impacts to generate an overall measure of the project's (financial) risk level. These linguistic values are used to derive the membership function (or single-factor evaluation vector) of each risk factor and the project risk level based on the collective judgments of the expert participants. 
205

206

207

208

209

210

211

212

213

214

215

216

217

218

219

220

221

222

223

224

225

226

227

228

229

230

231

232

233

234

235

236

237

238

239

\section{[Insert Table 2]}

Some applications of the FSE technique in different fields are summarized in Table 2. The table shows the extensive application and versatility of the method for modeling and decisionmaking processes in practical and complex multicriteria problems, including damage stage assessment of concrete structures (Liang et al., 2001), risk-based decision making (Sadiq et al., 2004), supplier selection decision-making (Pang and Bai, 2013), and urban infrastructure performance analysis (Khatri et al., 2011). Its applications establish the capability of the FSE to address qualitative multicriteria decision problems to arrive at useful decisions by modeling subjectivity and uncertainty in human experience and behavior (Boussabaine, 2014). In this regard, the authors aim to analyze financial risks in a BOOT water supply project and to predict the risk index of the project based on the experiential judgments of key project stakeholders. The risk index will depict the financial riskiness (risk level) of the project (i.e., 'not risky', 'moderately risky' or 'risky').

\section{Review of literature and project documentation}

Table 1 illustrates previous studies that had a specific focus on identification of financial risks and include the influential works of Lam and Chow (1999), Wang et al. (2000), and Xenidis and Angelides (2005). Lam and Chow (1999) surveyed financial risk variables at five phases of the BOT model in Hong Kong, namely: pre-investment, implementation, construction, operation and transfer. They elicited the general opinions of respondents regarding the significance of the risks, reporting that fluctuation in interest rate was the most significant variable at the pre-investment phase, whereas design deficiency and time overrun were highly significant at the implementation stage. Although the study of Lam and Chow enhances our understanding of financial risks in BOOT projects, it is time-bounded and hence, the significance of the reported risks may have declined or gained prominence over time. Given the study's focus on BOOTs in general, the important risks may not reflect those faced by water projects. Wang et al. (2000) surveyed practitioners' perception on the criticality of foreign exchange and revenue risks in BOT power projects. The authors reported that the important risks, in order of criticality, are tariff adjustment, dispatch constraint, foreign exchange, and financial closing risk. Drawing on the literature, Xenidis and Angelides (2005) provided a review and discussion regards checklist(s) of financial risks in general BOT infrastructure projects. However, the adopted research method was not designed for evaluating and prioritizing the risks. An alternative approach will be to subject the identified risks to a larger 
240

241

242 The review also included previous studies that reported on general risks in water-based BOOTs

rating panel or test the risks on an actual project. and utility PPPs (e.g., Şentürk et al., 2004; Zeng et al., 2007; Wibowo and Mohamed, 2010; Choi et al., 2010; Vives et al., 2006). Şentürk et al. (2004) examined a list of major risks associated with implementation of the Izmit Domestic and Industrial Water Supply BOT project in Turkey. Water sale price, land acquisition, return on equity, and determination of optimum operation period were some of the key risk issues reported. Zeng et al. (2007) carried out risk assessment/prioritization in BOT water supply projects in China based on eight risk categories, namely: political, bid and negotiation, economic, construction, operating, policy and legal, credit and force majeure. Regarding commercial risks, interest rate fluctuation, price variation of water resources, and foreign exchange rate volatility were found be critical. Research studies pertaining to risks associated with general BOOT projects in other infrastructure sectors (power/energy and transport) have also been reported (Yang et al., 2010; Lee and Schaufelberger, 2014; Rebeiz, 2012). In Ghana, literature relating to risk identification and allocation in utility water PPPs was reviewed (Ameyaw and Chan, 2013, 2015a, b). Ameyaw and Chan (2015a) presented a risk prioritization framework for water PPPs by using the Delphi method. Foreign exchange rate, corruption risk, water theft, non-payment of bills, and political interference were reported as the five most significant risks while expropriation, climate change, raw water scarcity, political violence and demand risks were found to be least critical.

The NSDP project was also analyzed to ascertain possible financial risks that may face it. The analysis was conducted through primary documentary review of contract documentation (concession agreement) and secondary documentary analysis of industry and professional reports, and newspaper articles. Merna and Smith (1996) noted that a concession agreement affords a useful source of information because it provides the basis of a long-term contract between private and public parties. It also identifies the risks and responsibilities linked to the financing, construction, operation/maintenance and revenue packages of a BOOT project. Table 3 reports upon the risks identified from related literature.

\section{[Insert Table 3]}

A preliminary list of 25 financial risks related to BOOT water supply projects in general and unique to Ghanaian environment was prepared following the literature review and documentary 
275

276

277

278

279

280

281

282

283

284

285

286

287

288

289

290

291

292

293

294

295

296

297

298

299

300

301

302

303

304

analysis (Table 3). Prior to preparing a questionnaire, the shortlisted risks were presented to a consultant (at Ghana's PPP Advisory Unit) for review and validation. The consultant was invited because of his direct involvement in the preparation of the concession agreement and risk-related negotiations, and has hands-on experience and specific knowledge on the NSDP. He also has 30 years of experience of Ghana's water industry and was available and willing to review the risks. Although the authors initially sought inputs from three practitioners, the other two indicated their unavailability. However, a review from the above-mentioned consultant is deemed sufficient given his participation, experience and knowledge on the project. The consultant was asked to indicate the important financial risks that apply to the NSDP project. Of the 25 risks short listed, 18 were verified and confirmed as 'significant' to the NSDP. Seven risks (unpaid bills by customers, supporting utilities risk, design deficiency, land unavailability, water theft by consumers, high bidding costs, and technology risk) were removed from the checklist, because they were not significant for the NSDP. Table 3 presents and compares the risks in the NSDP with those reported in the literature. It suggests that the shortlisted risks facing the project compares well with previously reported risks. The 18 risks were then formulated into a questionnaire for a survey.

\section{Questionnaire survey}

Project background - Nungua Seawater Desalination Plant (NSDP)

A questionnaire survey was conducted on the $\mathrm{NSDP}^{4}$ to measure how the project participants perceive the relative significance of the identified risks associated BOOT water supply projects in Table 3. This project is located in Ghana's capital city Accra and is selected because it is the first large-scale water supply project tendered on a long-term BOOT contract in the country. Therefore, the project provides a good example to further our understanding of risks. The NSDP project is a 25-year water purchase agreement between Ghana Water Company Limited (GWCL) and Befesa Desalination Development Ghana Ltd. (Befesa-Ghana: a consortium between Abengoa Water and Daye Water Investment). The NSDP project was finalized financially in November 2012 with a US\$88.7 million 12-year loan from the Standard Bank of South Africa, while the remaining US\$38.1 million came from stakeholder loan and equity. This arrangement resulted in a debt-to-equity ratio of 70:30 (Global Water Intelligence: GWI, 2012). This US $\$ 126.80$ million project involves the design, construction, operation and 
306

307

308

309

310

311

312

maintenance of a $60,000 \mathrm{~m}^{3} /$ day desalination plant with a water rate of US $\$ 1.36 / \mathrm{m}^{3}$. The construction duration of the NSDP project is 24 months. GWCL is the off-taker and is supported by a guarantee from the Ministry of Finance and Economic Planning (GWI, 2012; GWCL and Befesa Ghana, unpublished Water Purchase Agreement on NSDP, 2012).

\section{Survey and participants for risk assessment}

A risk assessment team of seven project participants having sufficient background knowledge of the PPP projects environment in Ghana and especially specific knowledge of and information on the NSDP project was created to assess the identified risks. This approach is acceptable and widely used in risk management research (e.g., $\mathrm{Ng}$ and Loosemore, 2007; Thomas et al., 2006). The PPP Advisory Unit (which manages and oversees public-private partnerships and serves as a centre of expertise) was approached to nominate participants with a direct involvement in the NSDP. Although the size of the risk assessment team is small, reliable assessment results is anticipated because the sample included top-level management officials with direct decision making roles in the project. The seven participants were involved in the preparation of contract documentation, risk-related negotiations and management of the NSDP.

Table 4 summarizes the participant's profiles; two from the client organization (GWCL), two from the local partner of the project (Hydrocol Ltd.), two from the PPP Advisory Unit, and one from the utilities regulator (Public Utilities Regulatory Commission (PURC). Although participants A and E have seven and four years of industry experience, respectively, they were deemed fit to participate in the survey because of their direct involvement in and subsequent knowledge of the NSDP project. The authors were not able to secure lenders' participation given their location outside Ghana and time limitation. There was however, participation from a local partner, Hydrocol Ltd. The participants were contacted ahead of time to explain to them the requirements and the questionnaire instrument which was then sent at a later date. The 
questionnaire was delivered in person, thereby allowing for clarification of any additional issues respondents might have. The questionnaire was then collected after two weeks.

\section{[Insert Table 4]}

As part of the assessment exercise, a questionnaire instrument was prepared based on the 18 risk factors for the purpose of eliciting the participants' opinions on these risks. The questionnaire was designed: (1) to gather perceptual rankings of the critical financial risks from persons with direct experience with the NSDP project; and (2) to measure NSDP's financial risk level. Part I of the survey instrument extracted contextual information on the respondents and their organizational affiliations, including their respective positions, years of water industry experience, and role in with the NSDP project. The rationale behind the risk assessment exercise and the contributions of participation in the research was clearly elucidated upon to all respondents (Dillman et al., 2008). Part II asked each project participant to independently rate the "criticality" of the shortlisted risks based on their perception and direct experience with / knowledge of the water project. Criticality is assumed as the joint effect of the likelihood of occurrence and the impact of the corresponding risk (Thomas et al., 2003). Wang et al. (2000) and Thomas et al. (2003) have used the criticality criterion for measuring BOOT project risks. A seven-point scale ranging from "Not critical" (NC) to "Extremely critical" (EC) was adopted for assessing risk criticality (see Table 5). These descriptive linguistic variables provided the participants with flexibility and the ability to measure the risks objectively and reliably (Shang et al., 2005). They also helped to generate rankings of the risks and their membership function sets (Chan, 2007) to quantify the criticality levels of the risks as well as and the overall risk index of NSDP. Based on the perceived criticality ratings of the risk assessment team, the mean criticality index, standard deviation, and criticality levels of the risks were calculated. The means criticality scores were calculated using Eq. (4) as follows. Standard deviation values were calculated using SPSS version 21.0 statistical package 21.0 (Pallant 2005). Additionally, 
a fuzzy based analysis on the risk factors was conducted to measure the risk level of the project.

361

362

363

364

365

366

367

368

369

370

371

372

373

374

375

376

377

378

379

380

381

382

383

384

385

386

387

388

389

390

391

392

393

394

\section{[Insert Table 5]}

\section{Evaluation of survey results and findings}

\section{Results obtained from FSE analysis}

Feedback from the risk criticality rating exercise was collated and analyzed. The FSE was adopted to quantify the impacts of the risks and to predict the financial risk level (FRL) of the case project. Figure 1 illustrates the operationalization of the fuzzy methodology adopted. The analysis provides a reliable and systematic method for evaluating and prioritizing the critical risks associated with the project and consequently quantifying its risk index, in order to enable a proactive project risk management. To assess the overall FRL of the NSDP project, both the weighting and membership functions of each risk factor were derived. Both functions of the risks were based on the ratings of the project participants according to the predefined descriptive linguistic variables. A fuzzy operator (discussed in step 4 below) was employed to process the weighting and membership function sets. FRL of the NSDP project contained 18 risks; thus, the multilevel and multifactorial fuzzy models (Li et al., 2000; Hsiao, 1998) were used to calculate the membership functions of the risk factors, to form the single-factor evaluation matrix $(\boldsymbol{R})$ (or fuzzy relational matrix in Fig.1) and to compute the single-factor evaluation vector $(\boldsymbol{D})$. In this regard, the FRL was derived by defuzzifying $\boldsymbol{D}$ through a set of indices, which defined the extent of the risk impact. The major steps in the fuzzy risk assessment process are detailed as follows.

\section{[Insert Fig. 1]}

\section{Step 1: Establish the set of basic risks and letter grades for evaluation}

The basic risks that affect the project are as follows (refer to Table 5): $\mathbf{r}_{1}=$ bankruptcy of consortium member(s), $\mathbf{r}_{2}=$ unfavorable economy of the host country, $\mathbf{r}_{3}=$ tariff adjustment uncertainty, and $\mathbf{r}_{18}=$ unfavorable economy of the country of the main stakeholders. Therefore, $\boldsymbol{\pi}=\left\{\mathbf{r}_{1}, \mathbf{r}_{2}, \mathbf{r}_{3}, \ldots, \mathbf{r}_{18}\right\}$. The set of qualitative classes (or linguistic variables) for the evaluation is as follows: $\boldsymbol{v}_{1}=$ 'not critical' (NC), $\boldsymbol{v}_{2}=$ 'very low criticality' (VLC), $\boldsymbol{v}_{3}=$ 'low criticality' (LC), $v_{4}=$ 'moderately critical' (MC), $v_{5}=$ 'critical' (C), $v_{6}=$ 'very critical' (VC), and $\boldsymbol{v}_{7}=$ 'extremely critical' (EC). Therefore, $\mathbf{V}=\left\{\boldsymbol{v}_{1}, \boldsymbol{v}_{2}, \boldsymbol{v}_{3}, \boldsymbol{v}_{4}, \boldsymbol{v}_{5}, \boldsymbol{v}_{6}, \boldsymbol{v}_{7}\right\}$. These linguistic variables were used to maximize the extensive knowledge of industry respondents, thereby minimizing 
395 subjectivity and vagueness in human perception, and to compute the linguistic variables for the 396 risk level in the NSDP project.

397

398 Step 2: Compute the membership function sets and impact scores of risks

399 The membership function set $\left(M F_{r_{i}}\right)$ of each risk can be derived by using fuzzy mathematics 400 based on the value judgment of the respondents. Given the seven linguistic variables in Step 1, 401 the membership function set of a particular risk $r_{i}$ is obtained through Equation (1) (Chan, 402 2007; Liu et al., 2013) as follows:

403

$$
M F_{r_{i}}=\frac{a_{i 1}}{v_{1}}+\frac{a_{i 2}}{v_{2}}+\ldots+\frac{a_{i n}}{v_{n}}=\frac{a_{i 1}}{\text { extremelylow }}+\frac{a_{i 2}}{\text { verylow }}+\ldots+\frac{a_{\text {in }}}{\text { extremely high }}
$$

404 where $a_{i k}$ is the membership grade and $a_{i k} / v_{k}$ signifies the relationship between $v_{i k}$ and 405 its $M F$ but not fractions. Thereafter, a single-factor evaluation vector for a risk $r_{i}$ is obtained 406 (Li et al., 2000) as follows:

407

$$
M F_{r_{i}}=\left(a_{i 1}, a_{i 2}, \ldots, a_{i n}\right)
$$

408 Consequently, the single-factor evaluation vectors of all the 18 risks are expressed in a fuzzy 409 relational matrix as follows:

$$
R=\left|\begin{array}{l}
M F_{r_{1}} \\
M F_{r_{2}} \\
M F_{r_{3}} \\
M F_{r_{4}} \\
M F_{r_{5}} \\
M F_{r_{6}} \\
M F_{r_{7}} \\
M F_{r_{8}} \\
M F_{r_{9}} \\
M F_{r_{10}} \\
M F_{r_{11}} \\
M F_{r_{12}} \\
M F_{r_{13}} \\
M F_{r_{14}} \\
M F_{r_{15}} \\
M F_{r_{16}} \\
M F_{r_{17}} \\
M F_{r_{18}}
\end{array}\right|=\left|\begin{array}{llll}
a_{11} & a_{12} & \ldots & a_{17} \\
a_{21} & a_{21} & \ldots & a_{27} \\
a_{31} & a_{32} & \ldots & a_{37} \\
a_{41} & a_{42} & \ldots & a_{47} \\
a_{51} & a_{52} & \ldots & a_{57} \\
a_{61} & a_{62} & \ldots & a_{67} \\
a_{71} & a_{72} & \ldots & a_{77} \\
a_{81} & a_{82} & \ldots & a_{87} \\
a_{91} & a_{92} & \ldots & a_{97} \\
a_{101} & a_{102} & \ldots & a_{107} \\
a_{111} & a_{112} & \ldots & a_{117} \\
a_{121} & a_{122} & \ldots & a_{127} \\
a_{131} & a_{132} & \ldots & a_{137} \\
a_{141} & a_{142} & \ldots & a_{147} \\
a_{151} & a_{152} & \ldots & a_{157} \\
a_{161} & a_{162} & \ldots & a_{167} \\
a_{171} & a_{172} & \ldots & a_{177} \\
a_{181} & a_{182} & \ldots & a_{187}
\end{array}\right|=\left|\begin{array}{lllllll}
0.00 & 0.00 & 0.00 & 0.00 & 0.33 & 0.33 & 0.33 \\
0.00 & 0.00 & 0.00 & 0.14 & 0.14 & 0.57 & 0.14 \\
0.00 & 0.00 & 0.00 & 0.29 & 0.14 & 0.14 & 0.43 \\
0.00 & 0.00 & 0.00 & 0.29 & 0.14 & 0.29 & 0.29 \\
0.00 & 0.00 & 0.00 & 0.00 & 0.57 & 0.29 & 0.14 \\
0.00 & 0.00 & 0.00 & 0.00 & 0.43 & 0.57 & 0.00 \\
0.00 & 0.00 & 0.00 & 0.00 & 0.67 & 0.17 & 0.17 \\
0.00 & 0.00 & 0.00 & 0.17 & 0.50 & 0.00 & 0.33 \\
0.00 & 0.00 & 0.00 & 0.00 & 0.71 & 0.14 & 0.14 \\
0.00 & 0.00 & 0.00 & 0.14 & 0.29 & 0.57 & 0.00 \\
0.00 & 0.00 & 0.00 & 0.40 & 0.20 & 0.00 & 0.40 \\
0.00 & 0.00 & 0.00 & 0.43 & 0.14 & 0.14 & 0.29 \\
0.00 & 0.00 & 0.17 & 0.17 & 0.33 & 0.00 & 0.33 \\
0.00 & 0.00 & 0.00 & 0.14 & 0.57 & 0.29 & 0.00 \\
0.00 & 0.00 & 0.00 & 0.43 & 0.14 & 0.29 & 0.14 \\
0.00 & 0.00 & 0.00 & 0.14 & 0.57 & 0.29 & 0.00 \\
0.00 & 0.00 & 0.00 & 0.43 & 0.14 & 0.29 & 0.14 \\
0.00 & 0.00 & 0.00 & 0.29 & 0.43 & 0.14 & 0.14
\end{array}\right|
$$

412 After deriving the membership function set of each risk in Equation (3), an index suggested by 413 Chen (1998) was used to compute the 'mean criticality' $\left(Z_{i}\right)$ of each risk to determine its rank 
414 and degree of criticality to the project. Criticality index of each risk is obtained by

415 defuzzificating its membership function set using Equation (4). The reason for using Equation

416 (4) is that the risk criticality rating has drawn on the expert judgment of the respondents using 417 linguistic values (which can be considered an ordinal measurement system) and is 418 representative of the risk assessments of the respondents.

419

420

421

422

423

424

425

426

427

428

429

430

431

432

433

434

435

436

437

438

439

440

441

442

443

444

$$
Z_{i}=a_{i 1} k_{1}+a_{i 2} k_{2}+\cdots a_{i n} k_{i}=\sum_{i=1}^{\circ} a_{i j} k_{i}
$$

where

$Z_{i}$ denotes the mean criticality score for the $i$ th risk (a higher index indicates greater potential impact of the risk on the project),

$a_{i j}$ represents the degree of membership, and

$k_{i}$ represents a variable of varying impact level of a risk. The seven linguistic grades in Step $1\left(\boldsymbol{v}_{1}, \boldsymbol{v}_{2}, \boldsymbol{v}_{3}, \boldsymbol{v}_{4}, \boldsymbol{v}_{5}, \boldsymbol{v}_{6}\right.$, and $\left.\boldsymbol{v}_{7}\right)$ with the corresponding numeric grades $(1,2,3,4,5,6$, and 7 , respectively) assigned to them described the impact levels of the risks. The numeric grades were used to defuzzify the membership function sets of the risk factors.

The third column of Table 6 shows the computation of $Z_{1}$ to $Z_{18}$. Arranging the $Z_{i}$ values in decreasing order of magnitude can determine the impact levels and ranks of the risk factors. Consequently, the mean criticality score of a factor can be included in any of the seven bands of the transformed rating scale in Table 4 . Risks with $Z_{i}$ values $\geq 4.51$ are considered critical. Based on the transformed measurement scale in Table 4, a risk factor with $Z_{i}$ values $<4.51$ belong to NC, VLC, LC, or MC.

\section{[Insert Table 6]}

\section{Step 3: Compute the weighting functions of the risks}

The weighting function $w_{i}$ denotes the relative criticality of a risk evaluated by the project participants. In this research, the normalized mean method used (Yeung et al., 2007) for determining weighted key performance indicators for construction partnering projects. The weighting of each risk is derived by normalizing its mean criticality index through Equation (5) (i.e., dividing each index by the sum of the indexes). The weighting vector must also satisfy the following normality condition (Li et al., 2000): 


$$
w_{i}=\frac{Z_{i}}{\sum_{i=1}^{\circ} Z_{i}}, \quad 0<w_{i}<1, \text { and } \sum_{i=1}^{\circ} w_{i}=1
$$

446 Therefore, the normalized weighting function set is

447

$$
W_{r_{i}}=\left(w_{r_{1}}, w_{r_{2}}, \ldots, w_{r_{18}}\right)
$$

448 The fifth column of Table 5 presents the weighting functions of the risks. Figure 2 further 449 illustrates the weighting functions.

450

451

452

453

454

455

456

457

458

459

460

461

462

463

464

465

466

467

468

\section{[Insert Fig. 2]}

Step 4: Determine the fuzzy vector of the project risk level

From the fuzzy evaluation matrix $R$ in Equation (3) and the weighting function set $W$ in Equation (6), the following equation is employed to establish the fuzzy synthesis evaluation result, namely, the evaluation vector:

$$
R \circ W=D,
$$

$$
D=\frac{d_{1}}{v_{1}}+\frac{d_{2}}{v_{2}}+\ldots+\frac{d_{7}}{v_{7}} \quad\left(0 \leq d_{k} \leq 1\right)
$$

where $d_{k}$ is the membership function of the denominator $v_{k}$ with respect to the fuzzy evaluation vector $D=\left(d_{1}, d_{2}, \ldots, d_{7}\right)$. The symbol "o" refers to the fuzzy operation, which is performed by various mathematical functions (Lo, 1999). The accuracy of the assessment results depends on a careful selection of the appropriate function to process Equation (7). In the present study, the $M(\bullet, \oplus)$ (weighted mean) function is selected. This function is defined as follows (Hsiao, 1998):

$$
d_{k}=\min \left\{1, \sum_{i=1}^{\circ} w_{i} a_{i j}\right\}, \quad j=1,2, \ldots, n
$$

Li et al. (2000) and Hsiao (1998) posited that when the weighting $w_{i}$ satisfies the normality condition $\sum_{i=1}^{\circ} w_{i}=1$, the " $\oplus "$ degenerates to $\mathrm{M}(\bullet,+)$; thus,

$$
d_{k}=\sum_{i=1}^{\circ} w_{i} a_{i j}, \quad j=1,2, \ldots, n
$$


469 In this regard, Equation (10) accounts for the influences of all the risks, which is suitable for

470 evaluating the contribution of risks from a general perspective (Hsiao, 1998).

471

472

473

474

475

476

477

478

479

480

481

482

483

484

485

486

487

488

489

490

491

492

493

494

495

496

497

498

499

500

Therefore, by using Equation (8), the result of the fuzzy evaluation vector of the project risk level becomes

$$
D=\frac{0.00}{\text { extremely low }}+\frac{0.00}{\text { very low }}+\frac{0.01}{\text { low }}+\frac{0.19}{\text { moderate }}+\frac{0.36}{\text { high }}+\frac{0.25}{\text { very high }}+\frac{0.19}{\text { extremely high }}
$$

$$
=(0.00,0.00,0.01,0.19,0.36,0.25,0.19) \text {. }
$$

\section{Step 5: Defuzzify the fuzzy vector of the project risk level}

After establishing the fuzzy evaluation vector in Step 4, the FRL of the NSDP project was quantified by defuzzifying its membership function set through Equation (12). The risk score of this project can be included in any of the seven bands of the risk levels in the last column of Table 5, which range from extremely risky (ER) to not risky (NR).

$$
Z_{\mathrm{FRL}}=\sum_{k=1}^{\circ} d_{k} \cdot k=0.00 \times 1+0.00 \times 2+0.01 \times 3+0.19 \times 4+0.36 \times 5+0.25 \times 6+0.19 \times 7=5.4312
$$

The key assumption of the aforementioned fuzzy-based analysis is that all seven respondents are experienced in BOOT projects and highly familiar with the study project (Table 3) and thus, the reliability of their judgments is ensured. Notably the approach presented above analyses the influences of risks and determines a project's risk level but the management or mitigation of the risk items is beyond the scope of this research.

\section{Reliability analysis}

Table 7 provides important information termed "project risk level (score) if risk item is deleted." This follows measurement scales' reliability analysis (see Pallant, 2005). This information measures the effect or contribution of each risk factor to the overall risk score (index) of the case project. The risk scores are the scores of the overall risk level of the NSDP project if the corresponding risk is removed from the calculation of the fuzzy model. Therefore, the risk scores (which depict the project risk level) are based on 17 risk factors, excluding the corresponding risk factor. By comparing these risk level scores with the overall risk level score (5.43) obtained in Equation (12), any risk factor that effectively contributes to the FRL of the NSDP project should have a corresponding score $\leq 5.43$. By contrast, a risk factor that does not contribute will have a risk level score $>5.43$. However, this condition is not violated; thus, each risk factor effectively contributes to the financial risk level of the NSDP project. None of 
501 the risks should also be excluded from the 18 -factor risk list. Also, Table 7 implies that the

502 items in our measurement scale measured the same underlying construct and that the scale is

503 reliable and has a good internal consistency.

504

505

\section{[Insert Table 7]}

506

507

5. Discussion

508

The assessment results provide two major conclusions. First, the global risk level of the NSDP

509 project is 5.43, which suggests that the 18 risks collectively have a critical impact on the cash

510 flow and viability of this project. Therefore, the NSDP project can be described as financially

511 risky (R) (Table 5). This conclusion and the results clearly support the findings of previous

512 researchers that BOOT (water supply) projects are vulnerable to financial risks (Barnett, 2007;

513 Zheng et al., 2007; Vives et al., 2006; Lianyu and Tiong, 2005; Xenidis and Angelides, 2005;

514 Lam and Chow, 1999). Therefore, effective mitigation measures should be implemented to

515 neutralize the adverse consequences of the assessed risks. Second, all the financial risk factors

516 are risky because their mean criticality ratings, which range from 5.14 ('critical') to 6.00 ('very

517 critical'), are greater than the 4.51 threshold. Table 6 shows that eight risks are included in the

518 'very critical' band, while the remaining 10 risks are found in the 'critical' band. The top five

519 risks are briefly discussed here because they have 'very critical' scores and because of the space

520 limitation in this paper. The discussion is supported with references to similar examples to enrich our understanding of the risks.

522

523 The bankruptcy of consortium member(s) is assessed as the most critical risk with a 'very 524 critical' rating (Table 6). This risk informs public clients that the progress of a project can be 525 jeopardized in case the concessionaire files for bankruptcy. This information is critical because 526 a possible bankruptcy risk may or may not necessarily relate to the project in question but to 527 other business operations of the stakeholder(s) (Xenidis and Angelides, 2005). For example, in 528 the troubled Tampa Bay Seawater Desalination Plant, the Covanta Tampa Construction was 529 awarded a construction contract and a 30-year concession to operate and maintain the facility.

530 Vinning et al. (2005) explained that because of the poor and mistrustful relationship between

531 Covanta and Tampa Bay Water, the former filed for bankruptcy in October 2003; the primary 532 reasons include the energy crisis in California, which affected the cash flow of Covanta (Barnett, 533 2007), and to stop Tampa Water from terminating the partnership and replacing Covanta 534 (Vinning et al., 2005). Ultimately, the risk adversely affected the project in terms of cost and 
535 time because Tampa Water had to find another firm to replace Covanta and to address the

536 treatment problems of the plant (Wall, 2013; Barnett, 2007).

537

538 The unfavorable economy of the host country reminds public-private stakeholders that the

539

540

541

542

543

544

545

546

547

548

549

550

551

552

553

554

555

556

557

558

559

560

561

562

563

564

565

566

567

568 economic environment where a BOOT water scheme is to be implemented has a significant influence on the eventual success of the project (Xenidis and Angelides, 2005). This risk ranks second with a 'very critical' rating. This score indicates that the expert respondents are highly concerned with an unstable economy with structural deficiencies, an immature and undersized stock market, foreign exchange fluctuation, currency devaluation, and fluctuation in interest and inflation rates, as reflected in Ghana (Ameyaw and Chan, 2015a) and many other developing countries. The implication of this risk is that the host government may fail to meet agreed guarantees, honor its payments under the contract, or funding availability and cost slippage problems may occur; thus, demand for water product may decline (Lee and Schaufelberger, 2014). In the aftermath of the 1997 East Asian financial crisis, the Taiwanese currency was devalued by approximately $30 \%$, which resulted in a huge cost overrun of roughly US\$500 million in the Taiwan High Speed Rail project (Lee and Schaufelberger, 2014).

The uncertainty in the tariff adjustment of water products hints that the respondents are concerned with the commitment of the current or future government to accept upward adjustments of the operating tariff in case of unexpected macroeconomic conditions (e.g., high inflation rate, currency devaluation, foreign exchange risk, etc.) during the 25 -year concession period. Such conditions are frequently beyond the control of the concessionaire. In BOOT projects in China, tariff adjustment is the most critical risk because the government insists on tariff renegotiation on an annual basis; a government price control authority must also approve the adjustment (Wang et al., 2000, p. 202). The 'very critical' rating of this risk corroborates the findings of Choi et al. (2010) and Wibowo and Mohammed (2010) that tariff adjustment risk has damaging outcomes on private investments in water projects in developing countries.

This risk results in low operating margins and poor service levels, as well as renders the revenue flow and profit levels of a project unpredictable; thus, the long-term sustainability of the concessionaire and the project itself is threatened.

The rate of return restriction risk (profitability) reflects the decision of the current or future government to restrict or impose a cap on the rate of return of the investment of the project (e.g., if the returns of the investors are deemed excessive) (Xenidis and Angelides, 2005). Being 
569 the first capital-intensive BOOT water supply project in Ghana, the respondents are concerned

570 that a future government may retain a rate of return for the investment. Experience shows that

571 rate of return restrictions frequently occur in BOOT projects; for example, foreign investors in

572 China have raised concerns regarding the $15 \%$ cap of the authorities on the rate of return of 573 private investment projects (Lee and Schaufelberger, 2014; Wang et al., 2000). Therefore, 574 imposing caps on the rates of return of projects has immense consequences, as reflected by the 575 'very critical' score of the risk. These consequences include a reduction in the viability of a 576 BOOT project because the cap limits the capability of investors to balance project risks with 577 corresponding returns (Wang et al., 2000), as well as proves difficult in attracting investors or 578 finances for infrastructure projects, as experienced in the Laibin B Power Plant in China (Lee 579 and Schaufelberger, 2014).

580

The availability problems of private sector capital reminds both the government and private 582 participants of the difficulties in raising sufficient finances on time for water infrastructure projects, particularly in developing countries. This difficulty is attributed to the reluctance of foreign donors and financial institutions to provide sizeable funds because of the perceived high risk profiles of these countries (Vives et al., 2006; Wang et al., 2000). With a 'very critical' score, the respondents are concerned with funding unavailability until the completion of the water treatment plant construction. This concern stemmed from the event that when the NSDP project was first awarded to a Norwegian developer (Aqualyng) in 2008, the developer failed to raise finances from the international financial market, which led to the termination of the project in 2010 (GWI, 2012). In another example, a consortium of Mitsubishi and Anglian Water failed to implement the Beijing No. 10 Water Treatment plant due to inability to raise debt financing as a result of inadequacies in the financing policies and regulatory systems of China (Zhang and Biswas, 2013). The Chinese government imposes stringent capital requirements and limited financing routes on private firms and strictly regulates the approval process for the principal financing source - bank loans ( $\mathrm{Li}$ and Zou, 2011). This finding supports the results of previous studies (Li and Zou, 2011; Wang et al., 2000; Tiong, 1990) which demonstrated that a major aspect of the successful execution of the BOOT model is raising financing. Therefore, financing risk requires innovative approaches to the financing and security of private investments, such as providing government guarantees (foreign exchange guarantees, interest subsidies, revenue guarantees, tariff guarantees, off-take agreements, tax exemptions, and debt guarantees), sound contractual structures, and fair risk allocations. 
604

605

606

607

608

609

610

611

612

613

614

615

616

617

618

619

620

621

622

623

624

625

626

627

628

629

630

631

632

633

634

635

636

637

methodology is more suitable for the early phase of a BOOT or PPP project, as used for prioritizing major risk events that require further analysis or action by management and for measuring the NSDP's risk level. This process is important because it allows the determination of risks for a detailed analysis and pricing in the later stages of a project. The proposed methodology also has the advantage of minimizing subjectivity associated with the assessment of risks by the experts. By using linguistic variables and appropriate fuzzy mathematical algorithms, the weightings and memberships of all the risks are combined and transformed to reduce imprecision and vagueness (Lo, 1999). Therefore, the proposed method can improve the accuracy of the risk evaluation results.

\section{Limitations and further work}

The main limitations of this research lie in the perception-based assessment of a set of financial risks in a single case study and the small sample size of the risk assessment team of project participants. The risk list may not be representative of all BOOT water supply projects risks in the Ghanaian project environment. However, being the first BOOT project in the water sector, it is crucial to study it in order to determine the important risk issues. Also, multiple methods, including literature review and project documentary analysis, a discussion to review and validate the shortlisted risks, expert risk rating exercise, and fuzzy set analysis, were used for purpose of research validity. For a single case, the use of seven project participants with direct experience with the project may be considered appropriate. This study's sample size was similar to those of previous analyses. Thomas et al. (2006) and $\mathrm{Ng}$ and Loosemore (2007), for example, used six respondents for risk analysis in a single case study. This limitation is further addressed through the careful selection of members of risk assessment team. The selection process was guided by industry/sector expertise, hands-on experience with BOOT procurement, and familiarity with the NSDP project, and top-level officials of the project management team. The third limitation is that this research does not explore the mitigation or management of the identified financial risks as well as their relationship with other project risks.

The above limitations provide avenues for further research to enhance risk management in BOOT projects. Research should be conducted on more project cases to include possible risks missed in this research. Such a study should examine other important risk categories, including political, legal/regulatory, social and operational risks. Here, this research will apply other decision models to risk management in PPP projects; these methods include portfolio decision models (Convertino and Valverde, 2013) and global sensitivity and uncertainty analysis 
638 (GSUA) (Saltelli et al., 2008; Lüdtke et al., 2007). The research will also cross compare results

639 obtained from the fuzzy set theory with portfolio decision methods and GSUA and elaborate

640 on the strengths and weaknesses of the different methods. Related to the above, the third

641 limitation should be addressed by establishing the linkages or relationships among the different

642 project risk categories in order to develop a full understanding of NSDP project's

643 comprehensive risk management program. This will help to achieve and sustain efficiency in

644 managing this and other BOOT projects to realize prescribed objectives.

645

\section{Conclusions and significance}

647 The research aimed to identify and assess the critical financial risks associated with BOOT 648 water supply projects and to conduct an evaluation of the financial risk level of a selected 649 BOOT water project. The objectives were achieved by conducting a questionnaire survey on 650 the NSDP project in Ghana. A list of financial risks prepared based on review of literature and 651 project documentation were assessed by a team of seven participants with a direct involvement 652 in the project. A total of 18 risks were found to be 'very critical' or 'critical' to NSDP and this has given an insight into the important financial risks faced by large-scale water projects in developing countries. The research suggests the top-five critical risks to water BOOTs as bankruptcy of consortium member(s), the unfavourable economy of the host country, the uncertainty in the tariff adjustment of water products, restrictions on the rate of return, and the availability problems of the private capital.

658

659 Results obtained from FSE analysis indicates the NSDP project is financially risky to the 660 project stakeholders. The generated risk index encapsulates effects of all the 18 critical risks identified for the research. All these risks must be the initial focus of public and private sectors if they are to effectively manage the risks associated with BOOT projects. The results further suggest that several of the risks ranked most highly by the participants are directly associated with the economic or financial environment in Ghana. These risks include the unfavorable economy of the host country, availability problems of private sector capital, inflation rate volatility, high construction costs, foreign exchange rate risk, etc. A country's economic environment present significant risks to the infrastructure sector, given that such risks impact on financial structures supporting project sustainability. 
672 improves the accuracy of assessment results given its ability to effectively handle the 673 subjectivity of experts. Because the input data in FSE analysis are based on experts' perceived 674 judgements makes it suitable for the early phases of BOOT / PPP projects to determine 675 significant risks that require the attention of and detailed analysis by project managers.

676

677 The findings are of importance to the development of BOOT and PPP practice. The Ghanaian 678 Government has renewed its commitment to using PPPs for delivery of public infrastructure 679 and services, including water supply. The government has introduced a PPP policy (Private 680 Participation in Infrastructure and Services for Better Public Services Delivery) to encourage

681

682

683

684

685

686

687

688

689

690

691

692

693

694

695

696

697

698

699

700

701

702

703

704

705

706 and attract private sector participation. Currently, about 29 water supply projects are awarded or proposed to be delivered through PPP mode. These projects include major expansion and rehabilitation and greenfield projects (GWCL, 2011). Hence, the number of privatised water supply projects is expected to increase. Over the past decade, two BOOT water projects were initiated and eventually abandoned following a lack of assessment of: (1) public concern over water tariffs and foreign (private) company involvement in public water services delivery resulted in public resistance; (2) corrupt practices in contract award; and (3) unavailability of private capital (Ameyaw and Chan, 2015b). Thus, the BOOT procurement process generates major risks and will not be a mere vehicle for the government to provide bulk water supply but requires effective project risk management. In this process, identification and assessment of risks are useful procedures, given that risks must be identified before they can be assessed and prioritized and subsequently monitored and controlled. By focusing on the first privatelyfinanced BOOT project in the water sector and identifying the critical financial risks in the Ghanaian project environment, the public and private sectors would benefit: (1) private investors/developers become aware of important risks in the NSDP project and similar future projects; (2) local government is able to prepare specific guarantees to counter specific risks raised by this research; and (3) to enable allocation of resources (time, money and human) to appropriate project areas.

\section{Notes:}

${ }^{1}$ Contractual arrangements and the characteristics of BOOT or public-private partnership (PPP) projects are discussed in detail by Rebeiz (2012), Delmon (2001), and Merna and Smith (1996). Delmon specifically provided a commercial and contractual guide for water projects under PPP contracts.

${ }^{2}$ These contracts tap private sector's management expertise for efficiency improvement and better governance in public water utilities, with service delivery modalities such as service contracts, management contracts, and leases.

${ }^{3}$ The lack of assessment of consumer willingness to pay the higher tariffs resulted from the contract. After the civil unrest, the 
Government unilaterally revoked the rate increases. Following this decision, Aguas de Tunari withdrew from the agreement, as performance of the contract requirements was no longer financially viable without the rate increases. The resulting contract dispute went to the International Centre for Settlement of Investment Disputes.

${ }^{4}$ The demand for potable water outweighs supply in the urban centers of Ghana (Ameyaw and Chan, 2013, 2015b). The World Bank revealed that the urban water supply infrastructure funding gap in this country is approximately US $\$ 4$ billion for the next decade (Foster and Pushak, 2011). To address this imbalance, the Ghanaian government, through the Ghana Water Company Limited (hereafter, GWCL), initiated a BOOT project to develop a major water treatment plant for bulk water supply using seawater as the source.

\section{References}

Ameyaw, E.E. and Chan, A.P.C. (2015a). "Evaluating Key Risk Factors for PPP Water Projects in Ghana: a Delphi Study." Journal of Facilities Management, 13(2), 133-155.

Ameyaw, E.E. and Chan, A.P.C. (2015b). "Risk Allocation in Public-private Partnership Water Supply Projects in Ghana." Construction Management and Economics, 33(3), 187-208.

Ameyaw, E.E. and Chan, A.P.C. (2013). "Identifying Public-Private Partnership (PPP) Risks in Managing Water Supply Projects in Ghana." Journal of Facilities Management, 11(2), 152-182.

Barnett, C. (2007). Mirage: Florida and the Vanishing Water of the Eastern, University of Michigan Press. USA.

Boussabaine, A. (2014). Risk Pricing Strategies for Public- Private Partnership Projects, 1st edn., John Wiley \& Sons, Ltd, Oxford, UK.

Boussabaine, A. and Elhag, T. (1999). "Applying Fuzzy Techniques to Cash Flow Analysis." Construction Management and Economics, 17, 745-755.

Tah, J.H.M. and Carr, V. (2000). "A Proposal for Construction Project Risk Assessment Using Fuzzy Logic.” Construction Management and Economics, 18(4), 491-500.

Chan, C.T.W. (2007). "Fuzzy Procurement Selection Model for Construction Projects."Construction Management and Economics, 25(6), 611-618.

Chang, N.B., Chen, H.W. and Ning, S.K. (2001). "Identification of River Water Quality Using the Fuzzy Synthetic Evaluation Approach." Journal of Environmental Management, 63(3), 293-305.

Chen, S.J. and Hang, C.L. (1992). Fuzzy Multiple Attribute Decision-making: Methods and Applications, Springer-Verlag, Berlin.

Chen, S.Y. (1998). Engineering Fuzzy Set Theory and Application, State Security Industry Press, Beijing.

Cheung, E. and Chan, A.P.C. (2011). "Risk Factors of Public-private Partnership Projects in China: Comparison Between the Water, Power, and Transportation Sectors." Journal of Urban Planning and Development, 137(4), 409-415.

Choi, J., Chung, J. and Lee, D.-J. (2010). "Risk Perception Analysis: Participation in China's Water PPP Market.” International Journal of Project Management, 28, 580-592.

Convertino M, Valverde LJ Jr (2013). "Portfolio Decision Analysis Framework for Valuefocused Ecosystem Management." PLoS ONE, 8(6): doi:10.1371/journal.pone.0065056.

Delmon, J. (2001). Water Projects: A Commercial and Contractual Guide, Kluwer Law International, The Hague, The Netherlands.

Donaghue, B. (2002). Statistical Treatment of Build-own-operate-transfer Schemes, Working paper WP/02/167, International Monetary Fund. 
Farquharson, E., Torres de Mästle, C., Yescombe, E.R. and Encinas, J. (2011). How to Engage with the Private Sector in Public-private Partnerships in Emerging Markets, World Bank: Washington DC.

Foster, V. and Pushak, N. (2011). Ghana's Infrastructure: A Continental Perspective, Policy Research Working Paper No. 5600, World Bank: Washington DC.

GWI, Global Water Intelligence (2012). Ghana Water Company re-invents Itself, 13(11).

Hall, D. and Lobina, E. (2006). Pipe Dreams - Failure of the Private Sector to Invest in Water, Public Services International Research Unit, Greenwich University, UK.

Hsiao, S.-W. (1998). "Fuzzy Logic Based Decision Model for Product Design.” International Journal of Industrial Ergonomics, 21(2), 103-116.

Huang, M., Ip, W. H., Yang, H., Wang, X., and Lau, H. C. (2008). "A Fuzzy Synthetic Evaluation Embedded Tabu Search for Risk Programming of Virtual Enterprises." International Journal of Production Economics, 116(1), 104-114.

Khatri, K.B., Vairavamoorthy, K. and Akinyemi, E. (2011). "Framework for Computing a Performance Index for Urban Infrastructure Systems Using a Fuzzy Set Approach." Journal of Infrastructure Systems, 17(4), 173-175.

Lam, K.C. and Chow, W.S. (1999). "The Significance of Financial Risks in BOT Procurement." Building Research \& Information, 27(2), 84-95.

Lan, H., Ding, Y. and Hong, J. (2005). "Decision Support System for Rapid Prototyping Process Selection Through Integration of Fuzzy Synthetic Evaluation and an Expert System." International Journal of Production Research, 43(1), 169-194.

Lee, N. and Schaufelberger, J.E. (2014). "Risk Management Strategies for Privatized Infrastructure Projects: Study of the Build-operate-transfer Approach in East Asia and the Pacific." Journal of Management in Engineering, 30(3), 05014001.

Li, H., Chen, C.L.P. and Lee, E.S. (2000). "Factor Space Theory and Fuzzy Information Processing-Fuzzy Decision Making Based on the Concepts of Feedback Extension." Computers \& Mathematics with Applications, 40(6), 845-864.

Li, J. and Zou, P.X.W. (2011). "Fuzzy AHP-based Risk Assessment Methodology for PPP Projects.” Journal of Construction Engineering and Management, 137, 1205-1209.

Li, Z., Chau, C.K. and Zhou, X. (2005). "Accelerated Assessment and Fuzzy Evaluation of Concrete Durability.” Journal of Materials in Civil Engineering, 17(3), 257-263.

Liang, M.T., Wu, J.H. and Liang, C.H. (2001). "Multiple Layer Fuzzy Evaluation for Existing Reinforced Concrete Bridges." Journal of Infrastructure Systems, 7(4), 144-159.

Lianyu, C. and Tiong, R.L. (2005). "Minimum Feasible Tariff Model for BOT Water Supply Projects in Malaysia." Construction Management and Economics, 23(3), 255-263.

Liu, J., Li, Q. and Wang, Y. (2013). "Risk Analysis in Ultra Deep Scientific Drilling ProjectA Fuzzy Synthetic Evaluation Approach.” International Journal of Project Management, 31(3), 449-458.

Lo, S.M. (1999). “A Fire Safety Assessment System for Existing Buildings.” Fire Technology, 35(2), 131-152.

Lüdtke, N., Panzeri, S., Brown, M., Broomhead, D.S., Knowles, J., Montemurro, M.A. and Kell, D.B. (2007). "Information-theoretic Sensitivity Analysis: A General Method for Credit Assignment in Complex Networks." Journal of Royal Society Interface, 5(19), 223-235.

Ma, J., Bai, Y., Shen, J. and Zhou, F. (2013). "Examining the Impact of Adverse Weather on Urban Rail Transit Facilities on the Basis of Fault Tree Analysis and Fuzzy Synthetic Evaluation." Journal of Transportation Engineering, 140(3), 04013011.

Matsukawa, T., Sheppard, R. and Wright, J. (2003). Foreign Exchange Risk Mitigation for Power and Water Projects in Developing Countries, Energy and Mining Sector Board Discussion Paper, No. 9, World Bank, Washington DC. 
802

803

804

805

806

807

808

809

810

811

812

813

814

815

816

817

818

819

820

821

822

823

824

825

826

827

828

829

830

831

832

833

834

835

836

837

838

839

840

841

842

843

844

845

846

847

848

849

850

Merna, A. and Smith, N.J. (1996). Guide to the Preparation and Evaluation of Build-ownoperate-transfer (BOOT) Project Tenders, Asia Law \& Practice, Hong Kong.

Mi, C., Zhang, X., Li, S., Yang, J., Zhu, D. and Yang, Y. (2011). "Assessment of Environment Lodging Stress for Maize Using Fuzzy Synthetic Evaluation." Mathematical and Computer Modelling, 54(3), 1053-1060.

Ng, A. and Loosemore, M. (2007). "Risk Allocation in the Private Provision of Public Infrastructure." International Journal of Project Management, 25(1), 66-76.

Organisation for Economic Co-operation and Development (2009). Private Sector Participation in Water Infrastructure, International Water Association, London.

Pallant, J. (2005). SPSS Survival Manual: A Step by Step Guide to Data Analysis using SPSS, $2^{\text {nd }}$ ed., Allen \& Unwin, Australia.

Pang, B. and Bai, S. (2013). "An Integrated Fuzzy Synthetic Evaluation Approach for Supplier Selection Based on Analytic Network Process." Journal of Intelligent Manufacturing, 24(1), 163-174.

PMBOK (2008). A Guide to the Project Management Body of Knowledge (PMBOK Guide), Project Management Institute, Newton Square, PA.

Rebeiz, K.S. (2012). "Public-private Partnership Risk Factors in Emerging Countries: BOOT Illustrative Project." Journal Management in Engineering, 28(4), 421-428.

Sadiq, R. and Rodriguez, M.J. (2004). "Fuzzy Synthetic Evaluation of Disinfection byproducts - A Risk-based Indexing System." Journal of Environmental Management, 73, 1-13.

Sadiq, R., Husain, T., Veitch, B. and Bose, N. (2004). "Risk-based Decision-making for Drilling Waste Discharges Using a Fuzzy Synthetic Evaluation Technique." Ocean Engineering, 31(16), 1929-1953.

Saltelli A., Marco, R., Terry, A., Francesca, C., Jessica, C., Debora, G., Michaela, S., Stefano, T. (2008). Global Sensitivity Analysis: The Primer, John Wiley \& Sons, Ltd, Chichester, UK.

Shang, H. P., Anumba, C. J., Bouchlaghem, D. M., and Miles, J. C. (2005). “An Intelligent Risk Assessment for Distributed Construction Teams." Engineering, Construction, Architectural Management, 12(4), 391-409.

Şentürk, H., Yazici, G. and Kaplanolu, S. (2004). "Case Study: Izmit Domestic and Industrial Water Supply Build-operate- Transfer Project." Journal Construction Engineering and Management, 130(3), 449-454.

Tah, J.H.M. and Carr, V. (2000). "A Proposal for Construction Project Risk Assessment Using Fuzzy Logic." Construction Management and Economics, 18(4), 491-500.

Thomas, A.V., Kalidindi, S.N. and Ganesh, L.S. (2006). "Modelling and Assessment of Critical Risks in BOT Road Projects." Construction Management and Economics, 24(4), 407424.

Tiong, R.L.K. (1990). "BOT Projects: Risks and Securities." Construction Management and Economics, 8, 315-328.

Tran, D., Mashford, J., May, R. and Marlow, D. (2011). "Development of a Fuzzy Risk Ranking Model for Prioritizing Manhole Inspection." Journal of Computing in Civil Engineering, 26(1), 550-557.

Vining, A.R., Boardman, A.E. and Poschmann, F. (2005). "Public-private Partnerships in the US and Canada: There are no Free Lunches." Journal of Comparative Policy Analysis: Research and Practice, 7(3), 199-220.

Vives, A., Paris, A.M., Benavides, J., Raymond, P.D., Quiroga, D. and Marcus, J. (2006).Financial Structuring of Infrastructure Projects in Public-private Partnerships: An Application to Water Projects, Inter-American DevelopmentBank, Washington D.C. 
Wang, S.Q., Tiong, R.L.K., Ting, S.K. and Ashley, D. (2000). "Evaluation and Management of Foreign Exchange and Revenue Risks in China's BOT Projects." Construction Management and Economics, 18(2), 197-207.

Wall, A. (2013). Public-private Partnerships in the USA: Lessons to be Learned for the United Kingdom, Routledge, New York, USA.

Wibowo, A. and Mohamed, S. (2010). "Risk Critically and Allocation in Privatized Water Supply Projects in Indonesia.” International Journal of Project Management, 28(5), 504513.

World Bank (2012). Private participation in Infrastructure Database. Available at: http://ppi.worldbank.org/explore/ppi_exploreSector.aspx?sectorID=4 (accessed 01 March 2014).

World Bank (2014). Water PPPs in Africa, Available at: http://ppp.worldbank.org/publicprivatepartnership/sites/ppp.worldbank.org/files/documents/africa_water_ppps_in_afric a_en.pdf (Accessed 13 March 2015).

Xenidis, Y. and Angelides, D. (2005). "The Financial Risks in Build-operate-transfer Projects." Construction Management and Economics, 23(4), 431-441.

Yang, J-B., Yang, C-C. and Kao, C-K. (2010). "Evaluating Schedule Delay Causes for Private Participating Public Construction Works under the Build-Operate-Transfer Model." International Journal of Project Management, 28, 569-579.

Yeung, F.Y., Chan, A.P.C, Chan, D.W.M. and Li, L.K. (2007). "Development of a Partnering Performance Index (PPI) for Construction Projects in Hong Kong: a Delphi study." Construction Management and Economics, 25(12), 1219-1237.

Zadeh, L.A. (1965). "Fuzzy Sets." Information and Control, 8(3), 338-358.

Zhang, Y.L. and Biswas, A.K. (2013). Pros and Cons of PPP in Water Sector, Available at: www.chinadaily.com.cn/opinion/2013-05/02/content_16469406.htm (Accessed 25 November 2013).

Zeng, S.X., Wan, T.W., Tam, C.M. and Liu, D. (2007). "Identifying Risk Factors of BOT for Water Supply Projects." Proceedings of Institute of Civil Engineering (ICE), Water Management, 161(2), 73-81. 


\section{Tables}

Table 1. Previous specific studies on financial risks in BOOT projects

\begin{tabular}{|c|c|c|c|}
\hline Authors & Purpose / sector & Country & Significant financial risks identified- \\
\hline $\begin{array}{l}\text { Lam and Chow } \\
\text { (1999) }\end{array}$ & $\begin{array}{l}\text { A questionnaire survey to- } \\
\text { explore the significance of } \\
\text { financial risks in BOT- } \\
\text { projects in general- }\end{array}$ & $\begin{array}{l}\text { Hong } \\
\text { Kong }\end{array}$ & $\begin{array}{l}\text { Interest rate, design deficiency, time overrun, } \\
\text { competition, currency exchange restrictions, defective- } \\
\text { products or facilities. }\end{array}$ \\
\hline Wang et al. (2000) & $\begin{array}{l}\text { An international survey on the } \\
\text { eriticality of foreign- } \\
\text { exchange and revenue risks- } \\
\text { in BOT power projects- }\end{array}$ & China & $\begin{array}{l}\text { Foreign exchange rate, currency convertibility risk, } \\
\text { financial closing risk, dispatch constraint risk, tariff- } \\
\text { adjustment risk. }\end{array}$ \\
\hline $\begin{array}{l}\text { Xenidis and- } \\
\text { Angelides (2005) }\end{array}$ & $\begin{array}{l}\text { A review of the literature to } \\
\text { identify and categorize- } \\
\text { financial risks associated- } \\
\text { with BOT projects in generat }\end{array}$ & $\begin{array}{c}\text { Not } \\
\text { applicable }\end{array}$ & $\begin{array}{l}\text { Bankruptey, import/export restrictions, high- } \\
\text { construction costs, lack of guarantees, currency risk, } \\
\text { cost overruns, financing risk, loan risk, unfavourable- } \\
\text { local and international econemies, inflation risk, risk } \\
\text { ef pricing product, high bidding costs, etc. }\end{array}$ \\
\hline
\end{tabular}


Table 2. Selected previous studies on application of the FSE method

\begin{tabular}{|c|c|c|}
\hline Study & $\begin{array}{l}\text { Specific area of } \\
\text { application }\end{array}$ & Summary of application \\
\hline Liang et al. (2001) & $\begin{array}{l}\text { Damage stage } \\
\text { assessment of } \\
\text { structures }\end{array}$ & $\begin{array}{l}\text { FSE is applied to establish a multiple layer fuzzy model for } \\
\text { assessing the damage stage of reinforced concrete bridges. The } \\
\text { method is advantageous at assessing damage conditions of existing } \\
\text { concrete structures. }\end{array}$ \\
\hline Chang et al. (2001) & $\begin{array}{l}\text { River water quality } \\
\text { analysis }\end{array}$ & $\begin{array}{l}\text { Utilized the FSE methods to determine the water quality conditions } \\
\text { of the Tseng-Wen River system in Taiwan. The fuzzy approach is } \\
\text { helpful at developing sound water quality management strategies. }\end{array}$ \\
\hline Sadiq et al. (2004) & $\begin{array}{l}\text { Risk analysis decision- } \\
\text { making }\end{array}$ & $\begin{array}{l}\text { FSE-based framework is developed for selecting an optimal drilling } \\
\text { waste discharge option. }\end{array}$ \\
\hline Li et al. (2005) & $\begin{array}{l}\text { Concrete durability } \\
\text { assessment }\end{array}$ & $\begin{array}{l}\text { General FSE framework is developed for the evaluation of } \\
\text { accelerated concrete durability. The FSE's results are consistent } \\
\text { with that of the experimental results. }\end{array}$ \\
\hline Lan et al. (2005) & $\begin{array}{l}\text { Prototyping process } \\
\text { selection }\end{array}$ & $\begin{array}{l}\text { FSE and an expert system are integrated to design a decision } \\
\text { support system for selecting suitable rapid prototyping processes. } \\
\text { FSE rank orders the alternatives and selects the appropriate } \\
\text { prototyping system. }\end{array}$ \\
\hline Huang et al. (2008) & Enterprise risk analysis & $\begin{array}{l}\text { FSE is embedded in a tabu search algorithm for risk analysis in } \\
\text { virtual enterprises. It is used to tackle uncertainty and fuzziness. }\end{array}$ \\
\hline Khatri et al. (2011) & $\begin{array}{l}\text { Urban infrastructure } \\
\text { performance }\end{array}$ & $\begin{array}{l}\text { FSE method is proposed to synthesize performance indicators into } \\
\text { an index to assess the overall performance of individual urban } \\
\text { infrastructure systems. }\end{array}$ \\
\hline Mi et al. (2011) & $\begin{array}{l}\text { Environment lodging } \\
\text { stress }\end{array}$ & $\begin{array}{l}\text { The study assesses the environment stress lodging for maize, and } \\
\text { the overall stress level for various study sites are derived through } \\
\text { the FSE method. }\end{array}$ \\
\hline Tran et al. (2012) & Manhole inspection & $\begin{array}{l}\text { Developed a fuzzy risk ranking model based on fuzzy set and } \\
\text { analytical hierarchy process (AHP). FSE is performed to obtain the } \\
\text { fuzzy number of final risk rank. }\end{array}$ \\
\hline Liu et al. (2013) & $\begin{array}{l}\text { Construction risk } \\
\text { analysis }\end{array}$ & $\begin{array}{l}\text { A risk assessment model based on the FSE method is proposed for } \\
\text { construction drilling projects risk assessment. }\end{array}$ \\
\hline Pang and Bai (2013) & Supplier selection & $\begin{array}{l}\text { An analytical network process (ANP)-FSE supplier evaluation and } \\
\text { selection methodology is proposed, in which FSE is applied to } \\
\text { select a supplier alternative. }\end{array}$ \\
\hline Ma et al. (2014) & Urban rail facilities & $\begin{array}{l}\text { FSE is integrated with AHP to develop an AHP-FSE model for } \\
\text { assessing the impact of adverse weather on urban rail transit } \\
\text { facilities and to derive the risk level of an evaluation target. }\end{array}$ \\
\hline $\begin{array}{l}\text { Ameyaw and Chan } \\
(2015 \mathrm{~b})\end{array}$ & $\begin{array}{l}\text { Risk allocation } \\
\text { decision-making }\end{array}$ & $\begin{array}{l}\text { A fuzzy-based risk allocation model for the assignment of risks } \\
\text { between the public and private parties in PPP projects. }\end{array}$ \\
\hline
\end{tabular}


Table 3. Identification and comparison of financial risks from the NSDP project and the literature

\begin{tabular}{|c|c|c|c|c|c|c|c|c|c|c|c|}
\hline \multirow{2}{*}{ Financial risks } & \multirow{2}{*}{ 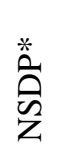 } & \multicolumn{10}{|c|}{ Selected references } \\
\hline & & $\Xi$ & $\widetilde{d}$ & $\bar{n}$ & 无 & $\sqrt{n}$ & $\sigma$ & $\Xi$ & $\infty$ & $a$ & $\dot{\mathrm{z}}$ \\
\hline Bankruptcy of consortium member/s & $\mathrm{x}$ & & $\mathrm{x}$ & & & & & & & & 1 \\
\hline Unfavourable (poor) economy in the host country & $\mathrm{x}$ & & $\mathrm{x}$ & & & $\mathrm{x}$ & & & & & 2 \\
\hline Tariff adjustment uncertainty of the water product & $\mathrm{x}$ & & & $\mathrm{x}$ & & $\mathrm{x}$ & $\mathrm{x}$ & $\mathrm{x}$ & $\mathrm{x}$ & & 5 \\
\hline Rate of return restrictions & $\mathrm{x}$ & & $\mathrm{x}$ & & & & & & $\mathrm{x}$ & & 2 \\
\hline Availability problems of the private capital & $\mathrm{x}$ & $\mathrm{X}$ & $\mathrm{x}$ & $\mathrm{x}$ & $\mathrm{x}$ & $\mathrm{x}$ & & $\mathrm{x}$ & $\mathrm{x}$ & $\mathrm{X}$ & 8 \\
\hline Inflation rate volatility & $\mathrm{x}$ & $\mathrm{x}$ & $\mathrm{x}$ & & $\mathrm{x}$ & $\mathrm{x}$ & $\mathrm{x}$ & $\mathrm{x}$ & & & 6 \\
\hline Lack of guarantees & $\mathrm{x}$ & & $\mathrm{x}$ & & & & & & & & 1 \\
\hline High construction costs & $\mathrm{x}$ & $\mathrm{X}$ & $\mathrm{x}$ & & $\mathrm{x}$ & & & $\mathrm{x}$ & & $\mathrm{x}$ & 5 \\
\hline Insufficient performance during operation & $\mathrm{x}$ & & $\mathrm{x}$ & & $\mathrm{x}$ & $\mathrm{x}$ & & & & & 3 \\
\hline Lack of creditworthiness & $\mathrm{x}$ & & $\mathrm{x}$ & & & & $\mathrm{x}$ & & $\mathrm{x}$ & & 3 \\
\hline Fluctuating demand & $\mathrm{x}$ & & & & $\mathrm{x}$ & $\mathrm{x}$ & $\mathrm{x}$ & $\mathrm{x}$ & & & 4 \\
\hline Prolonged approval time for the project & $\mathrm{x}$ & & $\mathrm{x}$ & & $\mathrm{x}$ & & & & & $\mathrm{x}$ & 3 \\
\hline Taxation risk & $\mathrm{x}$ & $\mathrm{X}$ & $\mathrm{x}$ & & & & $\mathrm{x}$ & & & & 2 \\
\hline Poor contract design & $\mathrm{x}$ & & & & & $\mathrm{x}$ & & & & & 1 \\
\hline Operation cost overruns & $\mathrm{x}$ & & $\mathrm{x}$ & & $\mathrm{x}$ & $\mathrm{x}$ & $\mathrm{x}$ & $\mathrm{X}$ & & & 5 \\
\hline Errors in forecasting the demand & $\mathrm{x}$ & & $\mathrm{x}$ & & & $\mathrm{x}$ & & & & & 2 \\
\hline Foreign exchange rate volatility & $\mathrm{x}$ & $\mathrm{X}$ & $\mathrm{x}$ & $\mathrm{x}$ & & $\mathrm{x}$ & $\mathrm{x}$ & $\mathrm{X}$ & & $\mathrm{X}$ & 7 \\
\hline $\begin{array}{l}\text { Unfavourable (poor) economy of the country of } \\
\text { the main stakeholders }\end{array}$ & $\mathrm{x}$ & & $\mathrm{x}$ & & & & & & & & 1 \\
\hline
\end{tabular}

*NSDP = Nungua Seawater Desalination Plant project

[1] = Lam and Chow (1999); [2] = Xenidis and Angelides (2005); [3] = Wang et al. (2000); [4] = Li and Zou (2011); [5] = Ameyaw and Chan (2015a); [6] = Zeng et al. (2007); [7] = Wibowo and Mohamed (2010); [8] = Choi et al. (2010); [9] = Lee and Schaufelberger (2014)

Risks not applicable to the NSDP project:

1. unpaid bills by customers; 2 . supporting utilities risk; 3 . design deficiency; 4 . land unavailability; 5 . water theft by consumers; 6 . high bidding costs; and 7. technology risk 
Table 4. Designation of members of the risk assessment team

\begin{tabular}{|c|c|c|c|c|c|}
\hline ID & Participant position & $\begin{array}{l}\text { Participant } \\
\text { organisation }\end{array}$ & $\begin{array}{l}\text { Years of water } \\
\text { industry } \\
\text { experience }\end{array}$ & $\begin{array}{l}\text { Familiarity } \\
\text { to NSDP } \\
\text { project }\end{array}$ & Participant role \\
\hline A & $\begin{array}{l}\text { Manager, Business } \\
\text { Planning }\end{array}$ & $\begin{array}{l}\text { Ghana Water Company } \\
\text { Ltd (GWCL) }\end{array}$ & 7 & $\begin{array}{c}\text { Very } \\
\text { familiar }\end{array}$ & $\begin{array}{l}\text { Member of the concession contract } \\
\text { preparation team. Involved in } \\
\text { project negotiations. }\end{array}$ \\
\hline B & $\begin{array}{l}\text { Director, Project } \\
\text { Development and } \\
\text { Investment }\end{array}$ & $\begin{array}{l}\text { PPP Advisory Unit - } \\
\text { Public Investment } \\
\text { Division }\end{array}$ & 25 & $\begin{array}{l}\text { Very } \\
\text { familiar }\end{array}$ & $\begin{array}{l}\text { Involved in all contract negotiations } \\
\text { with project developer/investors } \\
\text { for the government, including risk } \\
\text { allocation. }\end{array}$ \\
\hline $\mathrm{C}$ & Manager, Water Sector & $\begin{array}{l}\text { Public Utilities } \\
\text { Regulatory Commission } \\
\text { (PURC) }\end{array}$ & 30 & $\begin{array}{l}\text { Very } \\
\text { familiar }\end{array}$ & $\begin{array}{l}\text { Involved in the tariff review and } \\
\text { negotiations with the private } \\
\text { consortium. }\end{array}$ \\
\hline $\mathrm{D}$ & Project Manager & Hydrocol Ghana* & 13 & $\begin{array}{l}\text { Very } \\
\text { familiar }\end{array}$ & $\begin{array}{l}\text { Involved in all stages of the project, } \\
\text { risk-related negotiations with the } \\
\text { GWCL, PURC and sponsors. }\end{array}$ \\
\hline $\mathrm{E}$ & Project Coordinator & Hydrocol Ghana & 4 & $\begin{array}{c}\text { Very } \\
\text { familiar }\end{array}$ & $\begin{array}{l}\text { Project management team member } \\
\text { for the local private partner. } \\
\text { Involved in project negotiations, } \\
\text { such as tariff negotiations. }\end{array}$ \\
\hline $\mathrm{F}$ & $\begin{array}{l}\text { Project and Financial } \\
\text { Analyst }\end{array}$ & $\begin{array}{l}\text { PPP Advisory Unit - } \\
\text { Public Investment } \\
\text { Division }\end{array}$ & 35 & $\begin{array}{l}\text { Very } \\
\text { familiar }\end{array}$ & $\begin{array}{l}\text { In charge of project control and } \\
\text { financial feasibility for the } \\
\text { government. Involved in preparing } \\
\text { the contract agreement. }\end{array}$ \\
\hline G & $\begin{array}{l}\text { Manager, Projects } \\
\text { Construction and } \\
\text { Contracts Management }\end{array}$ & $\begin{array}{l}\text { Ghana Water Company } \\
\text { Ltd (GWCL) }\end{array}$ & 27 & $\begin{array}{c}\text { Very } \\
\text { familiar }\end{array}$ & $\begin{array}{l}\text { In charge of the project for GWCL. } \\
\text { Involved in preparing the } \\
\text { concession contract, negotiations } \\
\text { and finalizing the concession } \\
\text { agreement. Member of the project } \\
\text { management team. }\end{array}$ \\
\hline
\end{tabular}

*Local partner to the NSDP project

Table 5. Linguistic variables for quantifying risk criticality and project risk Not critical
$5.51-6.50$

Extremely risky


972

Table 6. Evaluation results of the financial risks

\begin{tabular}{|c|c|c|c|c|c|c|}
\hline ID & Critical financial risks & $\begin{array}{c}\text { Criticality } \\
\text { index }\end{array}$ & $\begin{array}{l}\text { Standard } \\
\text { deviation }\end{array}$ & $\begin{array}{l}\text { Weighting } \\
\text { function }\end{array}$ & Rank** & $\begin{array}{c}\text { Criticality } \\
\text { level* }\end{array}$ \\
\hline$r_{1}$ & Bankruptcy of consortium member/s & 6.00 & 0.89 & 0.061 & 1 & Very critical \\
\hline$r_{2}$ & Unfavourable (poor) economy in the host country & 5.71 & 0.95 & 0.059 & 2 & Very critical \\
\hline$r_{3}$ & Tariff adjustment uncertainty of the water product & 5.71 & 1.38 & 0.059 & 3 & Very critical \\
\hline$r_{4}$ & Rate of return restrictions & 5.57 & 0.53 & 0.057 & 4 & Very critical \\
\hline$r_{5}$ & Availability problems of the private capital & 5.57 & 0.79 & 0.057 & 5 & Very critical \\
\hline$r_{6}$ & Inflation rate volatility & 5.57 & 1.27 & 0.057 & 6 & Very critical \\
\hline$r_{7}$ & Lack of guarantees & 5.50 & 0.84 & 0.056 & 7 & Very critical \\
\hline$r_{8}$ & High construction costs & 5.50 & 1.22 & 0.056 & 8 & Very critical \\
\hline$r_{9}$ & Insufficient performance during operation & 5.43 & 0.79 & 0.056 & 9 & Critical \\
\hline$r_{10}$ & Lack of creditworthiness & 5.43 & 0.79 & 0.056 & 9 & Critical \\
\hline$r_{11}$ & Fluctuating demand & 5.40 & 1.64 & 0.055 & 11 & Critical \\
\hline$r_{12}$ & Prolonged approval time for the project & 5.29 & 1.38 & 0.054 & 12 & Critical \\
\hline$r_{13}$ & Taxation risk & 5.17 & 1.60 & 0.053 & 13 & Critical \\
\hline$r_{14}$ & Poor contract design & 5.14 & 0.69 & 0.053 & 14 & Critical \\
\hline$r_{15}$ & Operation cost overruns & 5.14 & 1.21 & 0.053 & 17 & Critical \\
\hline$r_{16}$ & Errors in forecasting the demand & 5.14 & 0.69 & 0.053 & 14 & Critical \\
\hline$r_{17}$ & Foreign exchange rate volatility & 5.14 & 1.21 & 0.053 & 17 & Critical \\
\hline$r_{18}$ & $\begin{array}{l}\text { Unfavourable (poor) economy of the country of } \\
\text { the main stakeholders }\end{array}$ & 5.14 & 1.07 & 0.053 & 16 & Critical \\
\hline
\end{tabular}

$*$ Refer to Table 4 for definition of terms and their ranges.

**Where two or more factors scored the same mean, the highest ranking is assigned to the one with the least standard deviation. 
Table 7. Checking reliability of the risk assessment result

\begin{tabular}{clcl}
\hline \multicolumn{4}{c}{ Overall project financial risk index $=5.43$ (Risky [R]) } \\
\hline ID & Critical financial risks & $\begin{array}{c}\text { Project risk level } \\
\text { (score) if risk item } \\
\text { deleted }\end{array}$ & $\begin{array}{c}\text { Linguistic } \\
\text { project risk } \\
\text { level }\end{array}$ \\
\hline$r_{1}$ & Bankruptcy of consortium member/s & 5.06 & Risky (R) \\
$r_{2}$ & Unfavourable (poor) economy in the host country & 5.10 & Risky (R) \\
$r_{3}$ & Tariff adjustment uncertainty of the water product & 5.10 & Risky (R) \\
$r_{4}$ & Rate of return restrictions & 5.11 & Risky (R) \\
$r_{5}$ & Availability problems of the private capital & 5.11 & Risky (R) \\
$r_{6}$ & Inflation rate volatility & 5.11 & Risky (R) \\
$r_{7}$ & Lack of guarantees & 5.12 & Risky (R) \\
$r_{8}$ & High construction costs & 5.12 & Risky (R) \\
$r_{9}$ & Insufficient performance during operation & 5.13 & Risky (R) \\
$r_{10}$ & Lack of creditworthiness & 5.13 & Risky (R) \\
$r_{11}$ & Fluctuating demand & 5.13 & Risky (R) \\
$r_{12}$ & Prolonged approval time for the project & 5.14 & Risky (R) \\
$r_{13}$ & Taxation risk & 5.16 & Risky (R) \\
$r_{14}$ & Poor contract design & 5.16 & Risky (R) \\
$r_{15}$ & Operation cost overruns & 5.16 & Risky (R) \\
$r_{16}$ & Errors in forecasting the demand & 5.16 & Risky (R) \\
$r_{17}$ & Foreign exchange rate volatility & 5.16 & Risky (R) \\
$r_{18}$ & Unfavourable (poor) economy of the country of the & 5.16 & Risky (R) \\
& main stakeholders & & \\
\hline
\end{tabular}

